Vol.3, No. 3, September 2021, pp. 400-409, doi.org:10.52567/pjsr.v3i3.264

www.pjsr.com.pk

\title{
GENESIS OF RADICALIZATION: A CASE STUDY OF ISLAMIYAT TEXTBOOKS IN BALOCHISTAN, PAKISTAN
}

\author{
Javed Ali Kalhoro \\ Assistant Professor, Department of Pakistan Studies and History \\ National University of Modern Languages, Islamabad \\ drjavedali@numl.edu.pk \\ Muhammad Zubair Iqbal \\ Pro Rector, National University of Modern Languages, Islamabad \\ drzubair.iqbal@gmail.com
}

\begin{abstract}
A high profile radicalization agenda in Pakistani schools and Islamic seminaries, across the country, has risen concerns within Pakistani society and for the world as well. Post 18th amendment in the constitution of Pakistan in April 2010, the education ministry dissolved to the provinces of Pakistan, with responsibilities to design their educational curriculums on their own. Since then, the four provinces of Pakistan have re-designed their curriculums and republishing textbooks as per their understandings. This article looks critically at one of the important and compulsory subjects; Islamiyat (Islamic Studies), arguing that the textbooks reassure the students towards a violent-radical mindset against the Kufar (non-believers). Such content in the textbooks also places its emphasis on the significance of Jihad (struggle) in the historical context of Islamic wars against the non-believers. The study brings quantitative and qualitative analysis, based on the Content Analysis application on the Islamiyat textbooks, mentioning the amount of positive and negative terms. The study also provides detailed denotations and connotations of the said terms to determine the outcome of the textbooks. The study suggests that the content in Islamiyat textbooks diverts the students from using education for fundamental social change to practice negative actions towards the Kufar. This study discovers that in the existing curriculum of Islamiyat, seemingly negative terms, such as Jihad has been presented as a physical war against the non-believers. The result also shows much emphasis on Mujahideen (Warriors of Islam) who lost their lives during wars against Kufar. Therefore, it concludes that presenting Islamiyat as the sole driver of radicalization among educated youth could result in a security threat to world peace.
\end{abstract}

Keywords: Radicalization, Education, Pakistan, Jihad, non-believers, global security

\section{INTRODUCTION}

This study employs the techniques of qualitative and quantitative analysis to discover a direct or indirect relation between Islamiyat textbooks and radicalization in Pakistani society. The qualitative analysis is used to examine the establishment, development, and impact of the education sector in Pakistan under different governments. For this purpose, this study employs the tools and techniques of historiography. Historiography provides a useful tool for examining the origins and evolution of the educational system in Pakistan. The historical data consists of history books, articles, official statements, and documents on the educational policies of Pakistan. This study also incorporates a quantitative content analysis of the existing text of the Islamiyat textbooks to quantify the use of certain terms, which may have radicalizing impacts on students. However, this study also keeps in view the contexts of these terms to avoid any speculative analysis. Moreover, this study has also collected and analyzed primary source data through semi-structured interviews of school teachers and other related individuals.

\section{The historical context of Islamic education in Pakistan}

Pakistan consists of four provinces; Sindh, Punjab, Khyber Pakhtoon Khuwa and Baluchistan. The country inherited these provinces after it lost its eastern wing in 1971, commonly known as East Pakistan, 
currently Bangladesh. Before this, Pakistan had two units; i.e. East Pakistan, which is now Bangladesh and West Pakistan, current Pakistan. The country enjoys its versatility of cultures, languages and history, since its inception on August 14, 1947.

As per the 1973 constitution of Pakistan, the country is administered as the Federal Republic and its official name is the Islamic Republic of Pakistan. The constitution also states that Muslims shall be permitted to practice their lives in individual/collective spheres as per teachings of Islam, set by the Holy Quran (Muslims' holy book) and Sunnah (practices by Muslim's Prophet Muhammad) (GoP, 2012). The constitution also instructs the state to provide all facilities for Muslims, which would enable them to understand the basic concepts of Islam and Sunnah. It further explains that the State teachings of the Quran and Islamiyat shall be compulsory to encourage people for learning the Arabic language and Holy Quran (GoP, 2012).

With this concept, the Islamiyat subject was made compulsory for all Muslims of Pakistan, during the Zia regime (1977-1988) known as Islamiyat (Islamic Studies) which aims at providing the basic education of Islam to the youth of Pakistan. The step aimed at putting the education system under the influence of Islam (Shah, Waris, Basit, 2016). Islamiyat is still being taught as a compulsory subject from early childhood to secondary level of education at the public schools of Pakistan. Similarly, as per the education policy of 1998-2000, the reason for the expansion of Islamiyat up to graduation level is to create a peaceful, and tolerant society with a broad vision of finding solutions to life through the Quran and Sunnah. During General Musharaf regime (1999-2008) as the president of Pakistan, an attempt was made to make certain changes in the Islamiyat textbooks to refrain from any sort of radicalism in the society. In 2002, General Musharaf gave the concept of "Enlighten Moderation" during his address at an Organization of Islamic Conference (OIC) Summit (Dawn News, 2003). Musharaf believed that Islam is not a fundamentalist religion as opposed to the teachings of the fundamentalist religious groups. While briefing the conference, Musharaf shared the following remarks about his strategy; "The world has been going through a tumultuous period since the dawn of the 1990s, with no sign of relief in sight. The suffering of the innocents, particularly my brethren in faith -- the Muslims -- at the hands of militants, extremists and terrorists has made it all the more urgent to bring order to this troubled scene. In this spirit, I would like to set forth a strategy I call Enlightened Moderation." (Washington Post, 2004). A policy draft was made with the title "National Curriculum Framework, Pakistan" to produce a new education policy for Pakistan, to be implemented by 2009. The policy draft demanded a change in the existing curriculum and recommended the following;

- “...To promote national cohesion by respecting all faiths and religions and recognize cultural and ethnic diversity.

- To promote social and cultural harmony through the conscious use of the educational process.

- To provide and ensure equal educational opportunities to all citizens of Pakistan and to provide minorities with adequate facilities for their cultural and religious development, enabling them to participate effectively in the overall national effort...." (GoP, 2018).

General Musharaf believed that global security faces a threat from religious extremism. He said that the production of suicide bombers from all over the world has ultimately produced a lethal force that is difficult to be countered (Washington Post, 2004). He also stated that the phenomenon of suicide bombers has resulted in the formation of negative perceptions of the teachings of Islam (Washington Post, 2004). He believed that his strategy of Enlightened Moderation would help to limit extremism and may also give out a message of peaceful Islam in the world. He believed that a negative impression about Islam at the global level would further promote extremism; therefore, it is important to reject the negative perception of the teachings of Islam. On the other hand, General Musharraf also took steps to promote education in Pakistan.

The education policy of 2009 could not be implemented as Musharaf lost his seat as the President of Pakistan. Later, the education ministry was dissolved and the provinces were given such responsibility to design and create their education curriculum and textbooks. 


\section{What do we understand by the term Radicalization?}

Radicalization is generally understood as a process or a particular view, which may cause an individual or a group to take an extreme position/action. However, the existing literature on Radicalization lacks a proper cohesive definition or explanation (Khan, Khan, Aziz \& Shah, 2012). As a result, there is no unified definition of this particular term. For this study, the term "radicalization" may be considered as a process where an individual, usually young people, are introduced to overtly ideological ideas that may result in encouraging extreme positions/actions (National Criminal Investigation, 2009). Radicalization among youth may be caused by several factors, such as poverty, unemployment, illiteracy, sectarianism, and injustice. However, the dissemination of radical messages or content can be regarded as one of the major contributors of radicalization among the educated youth in particular. In this regard, the system of formal education can play an important role in promoting or discouraging radical ideologies among young students. Formal education is used to disseminate knowledge of values, culture, and other fields of life. The definition of the word "Education" has changed from time to time. The conceptual features of Education involve different perspectives and ideas.

The Cambridge Dictionary defines aducation "the process of teaching or learning, especially in a school or college, or the knowledge that you get from this." (Cambridge, 2021). Similarly, the Oxford Dictionary explains education as; "The process of receiving or giving systematic instruction, especially at a school or university" (Oxford Online Dictionary, 2021). The above-mentioned definitions lead towards a conclusion that education is a scientific, psychological and philosophical procedure that allows an individual to perform his/her abilities at the fullest, as per the needs and demands of society.

\section{Islamiyat in Baluchistan}

In terms of its area, Baluchistan is the largest province of Pakistan, covering 347,190 square kilometres of area (Britannica, 2021). Moreover, the province also holds strategic importance due to its geographical location and abundance of natural resources. Baluchistan borders Iran and Afghanistan. The province has faced several challenges due to internal security issues shaped by internal and external forces. Therefore, scholars and academics worldwide, have been pondering to understand the social and economic dynamics of this particular province (ICG, 2014). After the $18^{\text {th }}$ amendment in the constitution of Pakistan (1973) in April 2010, the country decided to dissolve many ministries including education, to the provinces. Since then, the provinces are solely been responsible for their respective education curriculums and the publication of textbooks (Dawn News, October 11, 2010). Moreover, as per directions, given in the constitution of Pakistan, each citizen of Pakistan shall be provided basic education including Islamic education at the government established schools (GoP, 2012). Generally, these schools are called Public Schools in Pakistan.

Islamiyat is taught as a compulsory subject across the educational institutes of Pakistan, and it entails a study of the tenets of Islamic ideology. Officially, the purpose of this teaching is to introduce the students to Islamic Ideology and its relationship to national identity (Durrani, 2008). However, critics claim that the existing curriculum of Islamiyat carries negative undertones, which may directly contribute towards the radicalization of certain segments of the society (Fair, Shapiro, Malhotra, 2010). Considering the explanation of radicalization and concerns placed by the international scholars, this study carries six positive terms and six negative terms to find out in the existing Islamiyat textbooks.

The following table is designed to find out the number of certain words, which are assumed to be negative terms. Such as;

\begin{tabular}{|l|l|l|l|l|l|}
\hline Jihad & Mujahid/Mujahideen & Jang & Dushman & Hathiyar & Kafir/Kufar \\
\hline Effort/Fight & Warrior/Fighter & Fight & Enemy & Weapon & Non-believer \\
\hline
\end{tabular}

(The first row of this table contains the actual terms in Urdu language and the second row contains English translation of the said terms)

On contrary, the study also searches for the positive/soft words in the same Islamiyat textbooks to have a comparative analysis through quantifying the negative and positive terms. Such practice is being 
made to balance this study and lower the biases in the results. The positive terms in the same Islamiyat textbooks are as follows,

\begin{tabular}{|l|l|l|l|l|l|}
\hline Aman & Hum Ahangi & Ravadaari & Mohabat & Miyanaravi & Insaniyat \\
\hline Peace & Harmony & Tolerance & Love & Moderate & Humanity \\
\hline
\end{tabular}

The quantification of the above-mentioned terms, used in Islamiyat, shall define the actual status of Islamiyat textbooks, as to whether the subject plays any role in promoting wars or peace. In other words, the number of such words will decide the potential of radicalization or any possibility of violent radicalism among the students of primary and secondary schools in Pakistan.

According to a psychologist based in Islamabad, children of the ages 4 to 10 , absorb every information and knowledge given to them through formal or informal interactions. All the data that the children receive goes into their mind-hard disk; as a result, they build up a belief system and then act accordingly (Interview with Psychologist, 2019). He further explains that the children's reaction also depends on their surroundings and the social structure. Any positivity or negativity around them influences their mental growth. Learning positive and negative terms is also a part of this process.

\section{Application of Content Analysis}

Like other provinces, the Islamiyat subject is compulsory for each of the students from class primary to secondary levels. The content and the chapters of the Islamiyat are almost the same as in other provinces however, the contextualization of such chapters is slightly different. This is the reason that the quantitative results of Islamiyat in Balouchistan is different. Before proceeding towards the further discussion, the following chart must be examined to understand the use of certain terms in Islamiyat textbooks of Baluchistan;

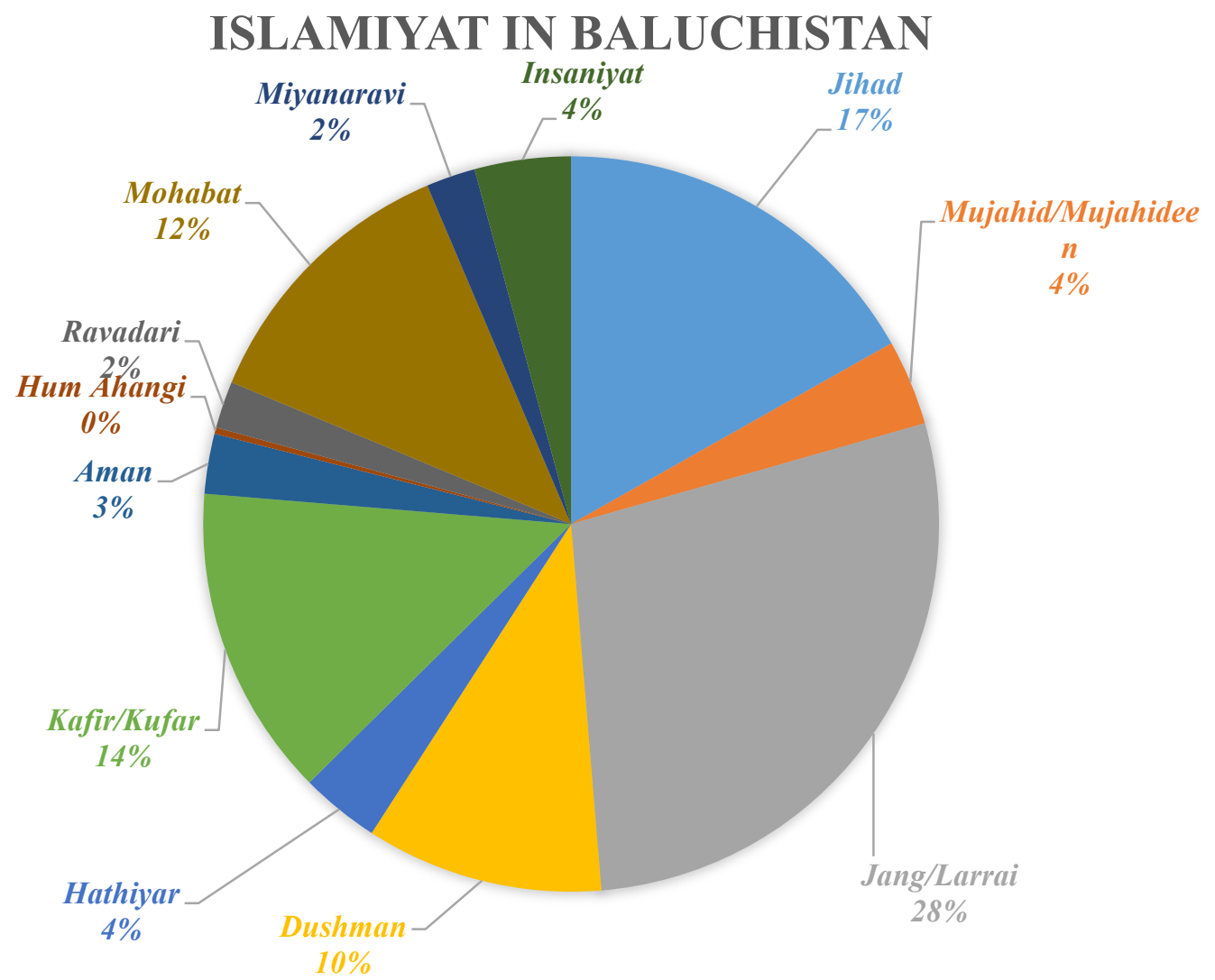

The above results show that the quantity of negative terms is more than the positive terms. The connotation and denotation of the hard or negative terms are not necessarily negative every time. 
However, the term Jihad has the same meaning and explanation as mentioned above in the section. The quantification of the said terms/words was analysed and concluded that there are certain sentences, which may not suit the level of students. For example, at one level, while discussing the historical war, there is a sentence that explains how Hazrat Ali killed the enemies by using his sword and chopping the head of the enemy etc. Such sentences may leave negative impressions of the development of young minds of the students. On the other hand, the class teacher would also explain the process of war with further details, which may place a negative impression on the student's psychological development (Interview, 2019). Moreover, there are various lessons with regards to the life of Prophet Muhammad, however, the prophet's life has been projected as a warrior than being positioned as the peace-keeper. On the other hand, following the basic principles of Islam, the Islamiyat textbooks of Baluchistan also emphasize becoming a good Muslim and a good citizen of Pakistan. The subject also provides content that encourages the youth to pursue positive development for the country and becoming the safeguard of Pakistan.

\section{Terms: Denotations and connotations}

Before we proceed towards the conclusion, it is important to understand the contextualization or the connotations of the above-mentioned terms, which are considered to be negative and positive. This discussion occupies different definitions mentioned in the Islamiyat textbooks and by the scholars, who have been pondering upon the philosophical explanations of such terms.

\section{Negative terms:}

\section{Jihad means Fight}

The term Jihad is generally positioned as Muslims' wage to physical fights against non-believers. However, the term is not necessarily negative but the contextualization of this particular term can be used as negative. Such as; Jihad explains fight but it is not necessarily a physical fight. Therefore, the religious aspect of this particular term does not aim to encourage Muslims to pursue any offence. At times, this term is intended to fight against evil within own soul or fight for basic human rights. At many stages in the Islamiyat textbooks, this term has been used as a physical fight against "non-believers". Here, the contextualization of non-believers does not mean non-Muslims but those who do not believe in the "oneness of Allah (God)". Therefore, the major portion of Islamiyat textbooks carries such sentences which place an influence on historical fights against non-believers, in the name of spreading Islam or "protecting" Islam. Such explanations at the very early stage of a child may produce a tendency of radicalization in his/her mind, resulting in a negative approach towards every non-believer or nonMuslim. In nutshell, the contextualization of this term may not be negative but such explanations in the Islamiyat textbooks have negatively placed its influence. The term Jang carries seventeen per cent of the text in the Islamiyat.

\section{Mujahid means Warrior}

The term is not new to the world. Mujahid or Mujahideen (in plural) means warrior but the contextualization of this term in Islamiyat textbooks have been placed as the "warriors of Islam" or the "holy warriors". This particular term has mostly been used to present Mujahideen as heroes of Islam who "defended" Islam and saved Muslims from non-believers. The concept of being Mujahid somehow encourages the student to pursue the holy war against the non-believers. The term Mujahid or Mujahideen has been used in Islamiyat textbooks more often. The students are taught the role of Jihad and Mujahideen who protected Islam and killed Kufar. The Mujahid word carries four per cent of the text in the Islamiyat.

\section{Jang means War}

This particular term "Jang" provides multiple explanations in the Islamiyat textbooks. At various stages, this term appears to be a "physical war" however, at some levels within the textbooks, the term is aimed at fighting against evils through pure soul or education. Although, the different contextualization of this particular term is confusing. The main objective of the word "Jang" has mainly meant a "physical fight" or war at a broader level. This term has mostly been used to discuss historical wars between the 
then converted Muslims and non-believers, however, the main connotation of wars has been presented as defence and defending Islam from the evils. On the other side, the Jews have been projected as the main enemy of Islam. The term is introduced to the students with the connotation of Islamic war against Jews and other non-believers. This particular term has been used in the Islamiyat with twenty-eight per cent of the text.

\section{Dushman means Enemy (of Islam)}

The term "Dushman" or enemy has also been frequently used in all Islamiyat textbooks of Pakistan. This particular term mentions non-believers as the enemies of some of the groups who did not want Islam to be spread. Through different lessons in the Islamiyat textbooks, the students are taught that Islam has always remained under the threat by non-believers due to its successful diversity of laws. Such laws include equality between all humans and admitting the role of women in furthering the social fabric of Islam. The major portion of Islamiyat textbooks discusses the historical wars than posture the peaceful side of Islam. This factor undermines the overall outcome of this particular subject, which somehow, loses its credibility and produce fear among many class teachers (Interview, 2019).

\section{Hathiyar means Weapon}

The term Hathiyar (Weapon) has also been frequently used in the Islamiyat textbooks. The term is used to explain the historical wars during the time of the inception of Islam. Different weapons like arrows, swords have been constantly used to explain how the wars were fought to "protect" Islam and Muslims. Sword has mostly been used as a weapon of Hazrat Ali. The textbook states that Ali used to use the two-edged sword against the enemies of Islam. Meanwhile, since the textbooks contain more literature on historical wars, which are commonly called Ghazwaz (the wars which were fought by Prophet Mohammad) therefore, it is quite evident that the terms like Jihad, Muhahid, weapons, fights etc are more frequently been used to explain the stories of wars. The term has been carrying four per cent of the text in the Islamiyat textbooks.

\section{Kafir means Non-believer}

One of the most complicated terms that have been used in the Islamiyat textbooks is "Kafir" (Non-believer) or "Kufar" (Non-believers) in the plural. In certain chapters, the term "Kafir" means nonbeliever whereas, at some level, the term defines Jews as the non-believers or those who believed in multiple Gods than the singular one, which is Allah. However, the actual meaning of non-believer in Islam means the one who doesn't believe in the oneness of God. The term "Kafir" is derived from the Arabic language. The actual word is "Kufr" which means "Sin" whereas Kafir means the one who sins. However, the level of $\sin$ or the contextualization of sin is defined in Islamiyat anywhere, which determine a fact that the students do not know or understand the actual literary meaning of "Kafir" or "Kufar". As much as fourteen per cent of the text in Islamiyat mention this term.

\section{Positive terms:}

\section{Aman means Peace}

The term Aman is not frequently been used in textbooks. As per the quantitative results mentioned above, only three per cent of the entire text is used. Although, majority of the public and private schools across Pakistan do mention a message on the school walls that "Islam is the religion of peace" but on contrary, this particular term is not positioned well in the textbooks (Interview, 2019. Similarly, one of the class teachers of the Islamiyat subject believes that for the last many years, Islam has been postured as a religion that supports terrorism. Although, it is "propaganda" but the government of Pakistan must realise that such content of the Islamiyat textbooks authenticates the "western version of Islam" (Interview, 2019).

\section{Humahangi means Interfaith}

This term has not been used even a single time in the Islamiyat textbooks. Although Islam does teach about respecting other faiths or religions, such lessons are visibly absent in the textbooks, which not only undermines the credibility of Islamiyat but it also raises many questions as well. One of the teachers believed that the subject of interfaith and harmony possess great importance because this particular subject presents Islam as the most vibrant and balanced religion (Interview, 2019). Moreover, the teacher 
believes that most of the teachers of Islamiyat or any other social sciences subject do discuss "respecting all religions" in the classrooms to create a peaceful environment across Pakistan. He also believed that the delivery of lectures plays a pivotal role in educating children than the text that students read in the textbooks.

\section{Ravadari means Tolerance}

Like many other positive things, Tolerance also possesses great importance in Islam. The term "Ravadaari" has been used multiple times in the Islamiyat textbooks but with a very limited quantity. This particular term has mostly been used only in one chapter. The term is explained as a necessity to promote peace in Pakistan. However, there are even other chapters within the same Islamiyat textbooks, which present Muslims as victims and the community that has always been targeted by different religions. This is quite an interesting part, the term War has been used the most compare to tolerance and peace in Islamiyat. This shows a source bias in the textbook and also undermines the overall credibility of the textbook. The quantity of the term Ravadari has been used with only two per cent in the Islamiyat.

\section{Mohabat means Love}

The term "Love" has been used in the Islamiyat textbooks with quite appreciable quantity. This term is used with twelve per cent of the text, however, the quantity of the term is even lesser than Jihad, Jang, Mujahid and other terms with negative connotations. The term has mostly been used to mention Prophet Muhammad's love for Muslim Umah and the textbooks urged the students to spread love Muslim Ummah in the same manner. However, it is debatable that why only Muslim Ummah to be loved and why not other faiths too? The contextualization of this particular term encourages the students to create a Muslim society that should be based on love and respect for each other. The overall quantity of this particular term is more than any other positive term which justifies the fact that the Islamiyat textbooks do emphasize the positivity of Islam.

\section{Miyanaravi means Moderate}

The contextualization of "Moderate" has remained very positive in the Islamiyat textbooks across Pakistan. The chapter "Miyanaravi" in the Islamiyat textbook, actually encourages the students to bring some positive changes in their lives such as; refrain from telling lies, over-exaggeration, controlling expenses and being a good citizen of Pakistan. Islam does emphasize all these factors; thus, mentioning such lessons in the Islamiyat textbooks are appreciable developments. The quantity of this particular term remains with two per cent of the text in the Islamiyat textbooks.

\section{Insaniyat means Humanity}

The term Insaniyat or Humanity (in English) seemed to be very rare in the Islamiyat textbooks. Although Islam does teach about respecting humanity and getting connected with people, belonging to all walks of life, such deficiency of lessons in the Islamiyat produce many questions for a researcher or scholar. The curriculum has been changed in the history of Pakistan, depending on different political, security and social phases. The current security situation in Pakistan and the world as a whole, demands such positive lessons of Humanity or Peace be taught to the younger generations so that they could be part of the peaceful global developments.

The above results indicate the inclusion of more negative terms than positive terms. However, at different levels, some of the terms do not necessarily promote a negative agenda. For example, the term Jihad provides the linguistic meaning of War. Scholarly, this particular term does not necessarily or exclusively give an impression of physical war against any individual, country or even community. Meanwhile, Jihad is discussed in Islamiyat textbooks as a separate chapter to provide students with a proper explanation of this particular term along with its types. According to the chapter Jihad has five types as described below;

1) Jihad Bin-Nafs means a fight with yourself

2) Jihad Bil-Maal means an effort to provide financial assistance

3) Jihad Bis-Saif means a fight for defence against your enemy (Physical)

4) Jihad Bi-Qalam means an effort through pen/writing

5) Jihad Bil-Lisan means a fight through tongue/words (Islamiyat class $\left.9^{\text {th }}, 2016\right)$. 
Out of the five types of Jihad, there is only one type that refers to a physical fight. On the other hand, most portions of the existing literature represent Jihad as a physical fight or war against the enemy. Meanwhile, Islamiyat textbooks in Baluchistan do not provide any further explanation of such types of Jihad in its lessons, rather, the textbooks place a huge emphasis on the historical portion of Islam by providing a simple justification of various wars against non-believers. Similarly, two of the Islamiyat teachers in Baluchistan contend that such lessons of historical wars in the textbooks appear to be "thrilling stories" for the students (Interview, 2019). One of the teachers believes that the students are particularly interested in such thrilling stories and somehow imagine themselves to be in the same situation. On the other hand, when the researcher interacted with some of the students to learn their understanding of Jihad, most of the students were not even aware of its proper definition or explanation. The only student of class $9^{\text {th }}$ believed that Jihad is necessary for every Muslim to ensure the security of Muslim Ummah (Muslim Community). On the other hand, an Islamabad-based Psychologist believes that youngsters tend to follow what they are taught. He said that students follow the lectures by the teacher much more than the text they read (Interview, 2019). Similarly, most of the literature on the quality of education in Pakistan suggests that the connotation of such lessons are highly sensitive therefore there should be proper teacher training to avoid any radical based or sensational lectures to the students. Considering this factor, there have been multiple non-governmental organizations who intended to pursue teacher training in Pakistan to improve the quality of education in the country, but, unfortunately, not a single organization has ever considered the Islamiyat teachers who direly need proper training before lecturing in the classrooms. Alif Ailan, a non-governmental organization in Pakistan, has been working in the education sector for many years. In its last report, published in 2015, the organization states that;

"Helplessness in education can be overcome if attempted. Massive numbers

of parents believe the myth that they cannot get their children educated because due to being poor. After some time, they just lose all hope in education and do not care about its terrible consequences."

One of the important points to be noted here is that education at public schools is free and so are textbooks. Like Alif Ailan, several governmental or non-governmental organizations have been pondering upon the number of schools than the quality of schools, several students in the schools than the quality of students who will be the pioneers of Pakistan. Secondly, as discussed earlier, there is a deficiency in the literature analyzing Islamic education in public schools. The prime reason for the second example is a security threat that scholars based in Pakistan try to avoid. There has only been one proper report on education in Pakistan that has rung the bells in Islamabad concerning radicalization in the public schools of Pakistan (The Subtle Subversion; The State of Curricula and Textbooks in Pakistan, 23003). The main architect of the document is Dr. Nayyer. Since 2003, there have been hardly a few articles that provide a detailed discussion on the possibility of radicalization in the public schools of Pakistan. In an interview, Dr. Nayyer said that he has been writing on education radicalization in some of the daily English newspapers but no such positive response has ever been received from him. He also said that he wrote a detailed report for the Jinnah Institute, an Islamabad based think tank, which has not been published due to security reasons (Interview, 2019).

The above-mentioned factors suggest that there is hardly an acceptance in Pakistan to discuss radicalization-free textbooks in the country. Having this idea in mind, when some of the teachers were approached for the interview, only a few responded in a very positive manner whereas the rest were reluctant to talk on Islamiyat subject. This factor once again indicates that there is pressure from the above level that does not accept any logical discussion to make positive changes in the existing curriculum. Meanwhile, the above data (in chart sheet) shows that the textbooks justify wars and enmity rather than fostering peace and interfaith. On the other hand, teachers further the discussion based on their understanding of the historical wars. Therefore, in totality, the students tend to have a negative sort of impression of the outside world, which somehow fills their minds with lots of misconceptions and misunderstandings.

\section{Teacher's response towards Islamiyat}


As discussed above, the role of teachers in this regard is highly crucial. One of the main reasons for the low quality of education in Pakistan is the deficiency in teachers training programmes. Considering the Pakistani culture, there have been hundreds of examples where the teachers are appointed based on their political affiliation with any party or religious group. Job hunters from religious groups are given the title of "Islamiyat teacher" where they serve their duty according to their understandings and their affiliation with religious groups. For example, the Jamaat-i-Islami has remained one of the critical religiouspolitical parties in Pakistan. The party believes in Nizam-e-Mustafa (A system prescribed by Prophet Mohammad) to serve their duties to spread the word of Prophet Mohammad across Pakistan. This is how, the political structure gets involved in the public schooling system in the country where the political parties intend to place their ideological understandings of Islam, into the curricula. One of the teachers believed that Jama-i-Islami has re-structured the curriculum designs by incorporating various lessons into the textbooks of Khyber Pakhtoon Khuwa and Baluchistan provinces, which are supporting radical sentiments among the youth of Pakistan. Meanwhile, the government, on the other hand, also endorses decisions made by the religious parties to enjoy their support (Interview with the subject teacher, 2019).

While conducting semi-structured interviews with the Islamiyat class teachers in different parts of Baluchistan, it was learned that the majority of the teachers were reluctant to share their analysis on Islamiyat textbooks and the curriculum development, saying that there is no question in Islam so there should be no question on Islamiyat textbooks too. However, there were only six teachers who responded to the questionnaire positively, requesting for keeping their privacy by not mentioning names in the article. These six teachers endorsed making certain changes in the Islamiyat textbooks. They believe that there should be more lessons on inter-faith harmony than the historical wars. One of the teachers suggested that students tend to visualize the historical wars they discuss in class, imagining themselves to be present in the situation and saving their Muslim brothers and sisters from outside "evils" and enemies of Islam. The teacher believed that such lessons in the textbooks should be rephrased or omitted from the textbooks. Another teacher suggested that the historical wars chapter should not be taught at the primary or secondary levels, rather, such lessons should be incorporated at the undergraduate level as the students are well-matured and more prepared to critically analyze the lessons at this developmental stage.

\section{CONCLUSION}

Based on the discussions mentioned above, it can be concluded that Islam emphasizes the acquisition and spreading of knowledge/education. It was also discovered that knowledge always had an importance in the Islamic civilization. Islam makes education or seeking knowledge compulsory and urges its adherents to distribute knowledge in the world. Moreover, Quran and Sunnah also promote the value of education and emphasize its significance in life.

Islam emphasizes exploring the aspects of human nature and the creation of the universe. Meanwhile, education in Islam is not limited to only acquiring knowledge but also to influence the character and nature of human beings so that they shall represent Islamic values in a better way. Such information and knowledge are classified as religious science of education which enables Muslims to acquire it as the blessing of God and Sunnah of Prophet Mohammad. Such things are quite fade or not visible when approaching the Islamiyat textbooks in Baluchistan province. Rather, the tantalization or content of the Islamiyat is seen to be more offensive and radical. Based on the interview with the psychologist and some of the teachers in Baluchistan, it was learned that even the relevant stakeholders are opposing the existing literature of Islamiyat. Pakistan is already surrounded by multiple security issues, Baluchistan is no exception. Therefore, there is a dire need of redesigning and republishing this particular subject to strengthen the credibility of Islamic education in the country and also to refrain from producing the next generations of violent radicals who may see the world as the enemy of Islam.

\section{REFERENCES}

Cambridge Online Dictionary $\quad$ (2021). Education.

http://dictionary.cambridge.org/dictionary/english/education 
Dawn News (October 14, 2003). US Supports enlightened moderation theory https://www.dawn.com/news/119988

Durrani, Naureen (April, 2008). Schooling the 'other'; the representation of Gender and National Identities in Pakistani Curriculum Texts. Compare; A journal of Comparative and International Education. 38(5). https://www.tandfonline.com/doi/abs/10.1080/03057920802351374

Fair, C. Christine, Shiparo, Jacob N., Malhotra, Neil A. (2010). Islam, Militancy and Politics in Pakistan: Insight from a National Sample", Terrorism and Political Violence. 22(4). https://papers.ssrn.com/sol3/papers.cfm?abstract id=1615764

Government of Pakistan (2012). The Constitution of Islamic Republic of Pakistan. http://www.na.gov.pk/uploads/documents/1333523681 951.pdf

Government of Pakistan (2018). National curriculum Framework of Pakistan. https://www.pc.gov.pk/uploads/report/NCF.pdf

International Crisis Group (2014, June 23). Education Reforms in Pakistan. Report No. 257. https://d2071andvip0wj.cloudfront.net/education-reform-in-pakistan.pdf

Khan, Prof. Dr. Rashind. Khan, Sareer. Aziz, Rukhsana \& Shah, Dr. Rehmat ullah (June 2012). Causes and Impact of Radicalization on Young People inside and outside of Pakistan. European Journal of Business and Social Sciences, 1(33)

National Criminal Investigation Canada (2009). Radicalization, A guide for the perplexed, https://cryptome.org/2015/06/rcmp-radicalization.pdf

Nayyar, A.H., Salim, Ahmed (2003). The Subtle Subversion; The State of Curricula and Textbooks in Pakistan. https://eacpe.org/content/uploads/2014/05/The-Subtle-Subversion.pdf

Oxford Online Dictionary (2021). Education. https://en.oxforddictionaries.com/definition/education

Shah, Ali, Waris, Muhammad, Basir, Abdul Islamization in Pakistan. (2016). A Critical Analysis of Zia's Regime. Global Regional Review. https://www.grrjournal.com/jadmin/Auther/31rvIolA2LALJouq9hkR/YxFmikmkcM.pdf

Washington Post (2014). A Plea for Enlighten Moderation. http://www.washingtonpost.com/wpdyn/articles/A5081-2004May31.html

Interview with A.H. Nayyer dated January 12, 2019.

Interview with Dr. Mubashir dated January 16, 2019

Interview with Islamiyat Subject Teachers dated March 10, 2019.

Interview with Islmiyat subject teacher dated March 8, 2019.

Islamiyat of class $9^{\text {th }}$, Baluchistan Text Book Board, 2014. 